Marsh, for long the assistant at Woolwich to Faraday, who from 1829 to 1851 was professor of chemistry at the Royal Military Academy, saw the close all too early of an ill-requited career, while the death at Chorlton-upon-Medlock of the manufacturer John Owens made available according to his will more than $£ 90,000$ for the foundation of an educational institution in Manchester. The well-known Owens College was opened in 1851, and from it sprang the University of Manchester.

Finally come the men of science and engineers from many lands who were born a century ago, and who in some cases were associated with those still living. Ira Remsen, the American chemist, who died in 1927, was of Dutch descent. $\mathrm{H}_{\theta}$ worked in laboratories in Germany, boing a fellow student with Sir William Ramsay at Tübingen, and in 1876 became the first professor of chemistry at the newly founded Johns Hopkins University, of which he ultimately became the president. In 1898 he was made a foreign member of the Chemical Society. While Remsen taught at Baltimore, Sir William Hartley, F.R.S., held the chair of chemistry in the Royal College of Science, Dublin. Known especially for his work in spectroscopy, he was a founder and the first president of the (Royal) Institute of Chemistry. He died in 1913, having been knighted two years before. Men of science in Poland have often worked under discouraging conditions, and this was the case with Karol Stanislav Olszewski (1846-1915), one of the leading investigators of low-temperature phenomena and the liquefaction of gases. He had lost his father in the insurrection of the peasants in 1846, but was able to qualify as a chemist under Bunsen at Heidelberg. He was then given the chair of chemistry at Cracow, where all his work was done. In more peace. ful Denmark, Poul la Cour (1846-1908) devoted himself to meteorology, and for a time was director of the government wind-power station at Askov, in Jutland. He was an inventor of scientific apparatus and edited Tycho Brahe's diary of 1582-96. Meteorology also claimed the attention of the Rev. John Mackenzie Bacon (1846-1904), of Trinity College, Cambridge. He went on eclipse expeditions, studied acoustics, took to kite-flying and ballooning and was a lecturer of distinction.

Various branches of engineering are recalled by the names of Durston, Watts, Westinghouse, Canet and Brandt. Engineer Vice-Admiral Sir John Durston (1846-1916) and Sir Philip Watts, F.R.S. (1846-1926) were both trained in the Royal Dockyards and the Royal School of Naval Architecture and Marine Engineering at South Kensington, Durston rising to the position of engineer-in-chief of the Fleet, while Watts from 1902 until 1912 was the director of naval construction and as such the designer of the famous battleship Dreadnought. George Westinghouse (18461914), who had German, Dutch and British blood in his veins, was one of the great figures in American engineering. When given the Grashof Medal by German engineers, the citation referred to him as "the pioneer of the automatic brake, the successful protagonist of alternating current, the meritorious designer of high-speed engines". Westinghouse was an industrialist on the grand scale. Jean-BaptisteGustave-Adolphe Canet (1846-1908) was as well known in the artillery world as was Westinghouse in the railway world. When he died he was president of the Junior Institution of Engineers, which founded the Gustave Canet Memorial Lecture in his honour. A different sphere of engineering is recalled by the career of Albert Brandt (1846-99). Born in Hamburg, he was a student in Zurich in the days of Zeuner, Culmann and Clausius. In 1875 he assisted in the construction of the St. Gothard Railway, and three years later entered into partnership with his countryman Karl Brandau (1849-1917). To Brandt and Brandau, together with the Swiss engineer Dr. Eduard Locher-Freuler (1840-1910), belongs the credit for the construction of the great Simplon Tunnel referred to by Prof. (now Sir) C. E. Inglis in a broadcast on October 25, 1942, as "the greatest epic in eivil engineering history" and "the most courageous victory ever won by engineers in their never-ending conflicts with the forces of Nature".

\section{WILLIAM CURTIS}

$\mathrm{W}$ ILLIAM CURTIS, founder of the Botanical Magazine and author of "Flora Londinensie", was born two hundrod years ago, on January 11, 1746, in Alton, Hampshire. The bicentenary of his birth is being celebrated, fittingly enough, at his birth-place, by an exhibition of manuscripts and other 'Curtisiana' to be opened on January 11 at the Alton Assembly Rooms, adjoining the Curtis Museum, of which Mr. W. Hugh Curtis, author of "William Curtis" (1941), is a joint honorary curator.

William Curtis was the son of a tanner of good Quaker family, and after leaving school was apprer. ticed to his grandfather, a surgeon-apothecary practising in Alton. William's early love of wild life was stimulated at this time by the ostler at the Crown Inn, one Thomas Legg, in whose company he searched the country round for plants and insects. His grandfather, however, disapproved of this deviation frcm the narrow path of an apothecary's curriculum, and William was packed off to the less tempting surroundings of London. Here he pursued his studies and in a short time inherited a business of his own in Gracechurch Street. But natural history was his first and true love and in 1771 he sold his practice and acquired an acre of land in Restoration Spring Garden, Bermondsey, for the culture of British plants. Various other projects, including the "Flora Londinensis", were already seething in his head, and he was now fairly launched on a botanical and entemological career. British botany at this time was badly in need of recruits. The Linnean system had recently been introduced into the country and workers were wanted to re-examine the British flora with a vigour and concentration that had boen lacking since the death of Ray in 1704.

Curtis, in 1771, was already closely in touch with many of the leading British botanists, but in 1772 he acquired cfficial status among them by his appointment as Praefectus Horti at the Society of Apothecaries' Chelsea Garden - a post he held until 1777.

Curtis's earliest two publications were entomological "Instructions for Collecting and Preserving Insects", 1771, and a translation of Iinnæus's "Fundamenta Entomologiae", 1772); but during his time at Chelsea, plans for his great work, "Flora Londinensis", were maturing, and the first number was issued in May 1775. Publication in parts continued until 1798, though not without the delays and complaints from subscribers that seem inseparable from such a method, and which Curtis's rather unbusinesslike disposition did nothing to mitigate. The two volumes in which the work is usually seen to-day 
appeared in 1777 and 1798. Curtis's aim was to produce a complete Flora of Britain, towards which the "Flora Londinensis" was to be a modest beginning; but the larger idea is represented only by a few non-London species included towards the end of the work. To the general public, then as now, the chief attraction of the "Flora" is the series of magnificent coloured plates, 435 in all, drawn and engraved by Sydenham Edwards, Kilburn, Milton, Sansom, James Sowerby and others. Three hundred copies of each part were printed and the plates were handcoloured by a team of some thirty colourists. But the text, to the botanist, is of equal or greater value. Sir James Smith ranked it "next to Ray's Synopsis in original merit and authority on British plants". Curtis was an acute and thorough worker, and in many difficult groups he brought order out of chaos, interpreting old names in the light of recent knowledge and describing several new species.

It is scarcely surprising that the sevverely botanical "Flora Londinensis" was not financially successful, and during its publication, in 1787, Curtis launched his second great venture, the Botanical Magazine, which recouped him handsomely for his linses. The Magazine, said Curtis, brought him pudding, while the "Flora" brought him praise. His aim, as described in the preface, was a work "in which Botany and Gardening ... might happily be ccmbined", and the fact that the magazine, with its beautiful coloured plates of gardon plants, is still appearing, after 160 years, is a tribute to his far-sighted estimate of horticultural and botanical needs.

In 1777, on giving up his post at Chelsea, Curtis began to move his garden from Bermondsey to Lambeth, "very near the Magdalen Hospital, St. Georges Fields, in the rcad from the said Hospital to Westminster Bridge Turnpike, through Lambeth Marsh Village". Here his "Lor don Botanic Garden" was opened on January 1, 1779. Curtis's two chief patrons were Daines Barrington and Thomas White, correspondent and brother, respectively, of Gilbert White of Selborne, and there were numerous subscribers of one and two guineas. Curtis remained at Lambeth until 1789, when, driven desperate by the effect of the London atmosphere on his plants, he again moved his Garden, to a site now occupied by the Brompton Hospital for Consumption, Fulham Road. After ten further years of fruitful botanical and entomological work he died at his home near the Gardens on July 7, 1799.

Curtis's main publications, apart from the "Flora Londinensis", the Botanical Magazine and his two early entomological works, were "Linnaeus's System of Botany" (1777), "A Short History of the Browntailed Moth" (1782), and "Practical Observations on the British Grasses", which ran to several editions. Reading Mr. W. Hugh Curtis's admirable biography, however, one realizes that Curtis's influence on con. temporary botany was due not only to his publications but even more, perhaps, to his friendships and correspondence with the leading botanists of the time, and to the establishment of his Garden as a rallying point for botanical endeavour throughout the country. Influence of this kind, however, though powerful at the time, becomes obscured with the passing of the years, and to-day Curtis's memory is kept green primarily by the nearly ten thousand plates and descriptions of the Botanical Magazine, and the two vast 'elephant folios' of "Flora Londinensis".

\section{J. S. L. GILMour.}

\section{Curtis as Naturalist and Humanist}

William Curtis placed the following inscription on the title-page of the second volume of his "Flora Londinensis"-"With wise intent the hand of Nature on peculiar minds imprints a different bias, and to each decrees its province in the common toil". How true that remark is will be evident if we compare him with some of those other strongly individual eighteenth century naturalists-Linnaus, to whcm, from boyhood until old age, systematy was the very breath of life, and whose greatness was proved in that hard task; Peter Collinson, that benign figure of a man, introducing new plants into English gardens from the American colonies and elsewhere, as well as several new correspondents to Linnxus; John Ellis, the discoverer, a man of keen eye and alert mind, who nevertheless left much of the actual work of classification to others; Daniel Solander, who, although Linnxus's ropresentative in England, was allowed by Sir Joseph Banks to publish so little; the two Martyns, with their solid classical learning; Gilbert White, who made good literature out of natural history and a beautiful Hampshire village; and many others who in varying degrees contributed to the progress of natural history in England during the eighteenth century.

Curtis became what he was born to become-a practical naturalist. His biographers mention the profound early influence of a local ostler, Thomas Legg, who was well read in the herbals of Gerard and Parkinson and could name most of the wild flowers around Alton. This was indeed the determining influence in Curtis's life, and one which lasted until he died at the comparatively early age of fifty. three. In that influence also is his link with the past, for just as the herbalists were bent on identifying living plants with those described or pictured in earlier herbals, so Curtis was fired with the ambition to describe and picture all the plants and animals of Great Britain.

Among the several biographies of Curtis, culminating with the excellent one by Mr. W. Hugh Curtis, "William Curtis, 1746-1799, Fellow of the Linnean Society, Botanist and Entomologist", published as recently as 1941, that by Samuel Good. enough in the Gentleman's Magazine for 1799 is surely the one in which we can see Curtis's personality most clearly; especially if we include the interesting extracts from Goodenough's letters to Curtis, to be found in Mr. Hugh Curtis's book. For twenty-three years, during the greater part of which Gocdenough was headmaster of a school at Ealing, he knew Curtis intimately. In the year of Curtis's death, Gocdenough became Canon of Windsor, and in later years, Bishop of Carlisle. $\mathrm{H}_{\Theta}$ was a very good classical scholar, and as one of the three founders of the Linnean Society of London had a great influence on its early years. In many ways he was exceptional-a Hercules of a man well over six feet in height, of great breadth of mind and with much downrightness of expression; a man of uncommon common sense combined with a deep sense of religion and with a very high respect for principles. Although he became well known as a botanical author, botany and entomology were only relaxations; his real life-work lay elsewhere. There must have been something extraordinarily fine about William Curtis for him to have earned and kept that friendship.

Goodenough's biography of Curtis is dated August 4, 1799, nearly a month after Curtis's death on 